\title{
RĪGAS PILSĒTAS SANITĀRĀS KOMITEJAS DIBINĀŠANA UN TĀS DARBĪBA 19. GADSIMTĀ
}

19. gs. Rīgã sākās strauja rūpniecības attīstỉba, ko îpaši veicināja pilsētas izdevīgais geogrāfiskais stãvoklis un plašie ekonomiskie sakari, kas arī sekmēja Rĩgas pilsêtas iedzīvotāju skaita pieaugumu.

Jau 19. gs. otrajā pusē Rīga kluva par svarīgu dzelzce|ja mezglu, jūras ostu un nozīmīgu rūpniecības centru ar ātri pieaugošu strādnieku skaitu.

Rīgã 19. gs. bieži plosījās holeras epidēmijas, plaši izplatītas bija bakas, dizentērija, izsitumu tīfs, vēdertīfs. Infekcijas slimības un epidēmijas parasti visvairāk skāra strādnieku apdzīvotos kvartālus, kur mitinājās liels iedzīvotāju skaits un sadzīves apstākli bieži vien bija visai nožělojami.

Cīna ar šìm slimībām un epidēmijām nostiprināja sabiedrības apziñã domu par nepieciešamību uzlabot Rīgas pilsētas sanitāro stāvokli. Pamatojoties uz Rīgas pilsễtas sešpadsmit ārstu iesniegumu civilajam gubernatoram, 1866. gada 7. martā tika nodibināta pagaidu Centrāla sanitārā komiteja, kas tûlît pievêrsa uzmanību stâvošu ūdeṇu likvidēšanai Rīgas pilsētas priekšpilsētās un izvirzịja jautājumu par pilsētas iedzīvotāju apgādi ar labas kvalitātes dzeramo ūdeni. Jau 1866. gada beigās kluva skaidrs, ka nepieciešams dibināt pastāvīgi darbojošos pilsētas Sanitāro komiteju. To izveidoja 1867. gada 9. augustā, pamatojoties uz valdības rỉkojumu, un 26. augustā tā sanāca uz savu pirmo paplašināto sēdi.

Sanitārās komitejas sastāvã bija divi priekšsēdētāji, pilsētas ârsts, divi ârsti un ḳīmiķis. Par tās prezidentu kluva viens no pilsētas mag̉istrāta locekliem.

Sanitārâs komitejas uzdevumus un pienākumus noteica speciāla instrukcija. Tajā bija teikts, ka Sanitārās komitejas mērķis ir nelabvēlīgu apstāklu un trūkumu atklāŠana Rīgas pilsētas sabiedrības veselības aizsardzībā un attiecīgu priekšlikumu un ieteikumu izstrādāšana, lai šos trūkumus novērstu. Instrukcijā bija arī norādīts, ka Sanitārā komiteja ir uzskatāma tikai par padomdevēju institūciju sanitărijas jautājumos. Šã iemesla dē| Sanitārăs komitejas izstrādātie priekšlikumi un ieteikumi ne vienmēr tika îstenoti. Bieži vien tie bija atkarīgi no citu iestāžu un nozaru darbības un lēmumiem, vai arī bija ar tiem saistīti. Lielu uzmanību Sanitārā komiteja veltỉja Rīgas pilsētas sistemātiskai attīrī̌sanai un atūdennošanai. Viens no 
pirmajiem priekšlikumiem bija ieteikums aizbērt pilsētas neciešami piesārṇotos grầvjus, kã arī veikt dažādus pasākumus, lai uzlabotu pilsētas kanāla sanitāro stāvokli.

Sanitārā komiteja norādīja arī uz nepieciešamību izstrādāt Rīgas pilsētas vispārējās kanalizācijas plânu, kā arī pati ieteica dažus ierosinājumus un piedalījās nepieciešamo priekšdarbu sagatavošanā. 1875. gadā pēc komitejas iniciatīvas tika uzsākts darbs pie notekūdeṇu novadī̌sanas vispārējās programmas projekta izstrādāšanas, un 19. gs. beigās Rīgã uzsāka kanalizăcijas ierīkošanu. Tomēr no šã projekta jau pašã sākumā bija izslēgti vairāki pilsētas nomalu rajoni, kã arī Daugavas kreisā krasta pilsêtas dạa.

Atzīstami bija Sanitārās komitejas nopelni ielu, pagalmu, laukumu tīrības un kārtỉbas uzlabošanã, it īpaši nomalēs un priekšpilsētu rajonos, kur stãvoklis bija sevišksi slikts. Tika sagatavoti un 1880. gadā izdoti statūti par pagalmu uzkopšanu un ielu un atklāto laukumu tīrī̌anu. Sanitārā komiteja pievêrsa uzmanība arī jaunu, visiem pieejamu dzilurbuma aku ierīkošanai priekšpilsētas kvartālos, tādējāidi uzlabojot turienes iedzīvotāju apgãdi ar dzeramo ūdeni. Pẽc komitejas ierosinājuma 1870. gadā un turpmākajos gados tika ierīkotas vairākas šădas akas, tomēr tās nespēja kopumā nodrošināt pilsētas iedzīvotāju apgādi ar labu dzeramo ūdeni.

Rīgas pilsētas Sanitārā komiteja pastāvēja līdz 1879. gadam. Jau 1878. gadā bija izdots rīkojums par jaunas pilsētas Sanitārās komisijas izveidošanu, kurai būtu daudz plašāki uzdevumi un pienākumi, joprojām saglabājot padomdevējas institūcijas funkcijas, pašai nepiedaloties uzdevumu veikšanā. Jaunajai Sanitărajai komisijai tika uzdota jau esošo, kā arī no jauna ierîkoto sanităro iestāžu tieša pārraudzība. Pienākumu un uzdevumu loks arvien paplašinājās, Sanitārās komisijas locek|iem bija arvien vairāk darba, tāpēc jau pirmajā komisijas pastāvēsanas gadā tika nolemts no 1880. gada pieņemt darbā speciālu ierēdni, kas koordinētu veicamos uzdevumus, nepieciešamības gadījumā pieaicinot citus Sanitārās komisijas locek|us. Sanitārās komisijas sākotnējais sastāvs izmainījās, kad 1883. gadā tika ierosināts palielināt komisijas ārstu skaitu par divām vietām un, sākot no 1885. gada, visiem cetriem ārstiem tika uzlikts par pienākumu veikt visus Sanitārās komisijas rīkojumus iedalītajā pilsētas rajonā.

Sanitārās komisijas pienākumos ietilpa arī pārraudzīt un rūpēties par pilsētas dzīvojamo platību sanitārhigiēnisko apstākḷ uzlabošanu. It îpaši tas attiecâs uz pagraba dzīvok|iem, kas tika iekārtoti pārkāpjot ēku celtniecības likumus, radot potenciālus epidēmiju perēkḷus. 1885.-1886. gadā Sanitārās komisijas locek|i veica visu pilsētas rajonu pagraba dzīvoklu apskati un ieguva satraucošus rezultātus. Tika konstatêti dzīvok|i, kuros grīdas, gruntsūdenim tikai nedaudz pace|oties, atradās ũdenī, bija tâdi, kur ũdens no ielẫm iesūcās dzĩvoklī, kā arī tâdi, kuru logi tikai mazliet pacēlâs virs ielas un līdz ar to dzīvoklos bija loti maz dienasgaismas. No 122 apsekotajiem dzĩvokliem Sanitārās komisijas locekli izdalīja tikai 19 dzīvok|us, kuros pẽc kârtīga remonta varēja radīt dzīvošanai piemērotus apstāklus, 
bet pārējos 103 pagraba dzīvok|us Sanitārā komisija pieprasịja likvidēt. Rūpēs par dzīvojamo platību sanitārhigiēnisko apstāklu uzlabošanu ietilpa arī jautājums par jaunuzcelto vairākstāvu ēku dzīvok|u izīrē̌anas noteikumu izstrādāšanu. Tie paredzēja, ka šãdos dzīvoklos drīkstēja ievākties tikai pēc tam, kad Sanitārā komisija bija tos apskatijjusi un atzinusi par pietiekami iž̌uvušiem un sausiem.

Palielinoties iedzīvotāju skaitam Rīgas pilsētā, pieauga arī ar sabiedrības veselības aizsardzību saistîto jautājumu loks, un drīz vien ārstu skaits pilsētas Sanitārajā komisijā izrādījās nepietiekams. 1891. gadā Sanitārā komisija izveidoja îpašu pilsētas sanitārā ārsta posteni, uzticot tam vairāku pilsētas sanitāro iestāžu - dezinfekcijas, baku potēšanas, glābšanas un sekciju kameras (morga) - pārzināšanu, kā arī detalizētu un vispusīgu slēdzienu un ieteikumu izstrādāšanu pilsētas Sanitārajai komisijai. Tã kā Sanitārā dienesta pienākumi arvien turpināja palielināties, 1893. gadā darbam Sanitărajā komisijă tika pieņemti vēl divi ārsti.

Sanitārās komisijas locekli piedalījās arī pilsētas skolu veselības aizsardzỉbā un sanitārhigiēnisko jautājumu risināšanā. Komisijas locek|i izstrādāja norādījumus par karantīnas ieviešanu skolās, sagatavoja un iesniedza priekšlikumus par vietas izvēli skolas celtniecībai u.tml.

Tầpat Sanitārā komisija aktīvi līdzdarbojās pilsētas centrālās lopkautuves iekārtošanas programmas izstrādāšanā, sanităro normatīvu sagatavošanā un lopkautuves celtniecỉbai piemērotas vietas izvēlē. Šādas oficiālas iestādes atvēršanas nepieciešamību noteica galvenokārt sanitārie apsvērumi, uz ko jau vairākkārt bija norāđijjusi pilsētas Sanitārā komisija, kurai pêc lopkautuves atvēršanas 1897. gadā, tika uzticêta arī tās pārvaldīšana. 19. gs. beigās Rīgā palielinājās sūdzību skaits par gaisa piesārnošanu ar dūmiem un kaitīgām gāzēm, kā arī apkārtnes piesārnošanu ar notekūdeṇiem un cieto vielu atkritumiem. Arī šie jautājumi bija jārisina pilsētas Sanitārajai komisijai, kas ik gadu ieteica dažādus priekšlikumus kaitīgo apstāklu mazināšanai un veica pasākumus to likvidēšanai. Sanitārās komisijas darbỉba Rīgas pilsētā turpināja paplašināties un, uz jaunā gadsimta sliekšña, 1900. gadā, tika nodibināta speciāla Veterinārā noda|a, kurā tika ieklauti arī visi pilsētas Sanitārās komisijas ārsti.

\section{Secinājumi}

Nodibinoties pastāvīgai Rīgas pilsētas Sanitārajai komitejai 1867. gadā, tâs darbība līdz 19. gs. beigām arvien vairāk paplašinājās, kluva vispusīgāka un daudzveidīgāka. Tas liecina par Sanitārās komitejas (vēlāk komisijas) nozīmīgumu Rīgas pilsētas iedzīvotāju veselības aizsardzỉbā un sanitārhigiēnisko apstāk|u uzlabošanā.

\section{Literatūra}

1. Feodālā Rĩga. - Rīga, 1978. - 310,-329. 1pp.; 378. Ipp.

2. Latvijas PSR Mazā enciklopēdija. - Rīga, 1970.-III sēj.-172. Ipp. 
3. Rīga: 1860-1917. - Rīga, 1978. - 16. lpp.; 19.-20. lpp.; 33. Ipp.

4. Bericht des permanenten Sanitäts-Comitee der Stadt Riga über seine Wirksamkeit im Jahre 1878. - Riga, 1879. - 4 S.

5. Carlberg N. Der Stadt Riga Verwaltung und Haushalt in den Jahren 1878-1900. Riga, 1901. - S. 49; 54; 60; 102; 114-118; 134-137; 143-144.

6. Hess N., Bochmann E. Über öffentliche Gesundheitspflege und die Wirksamkeit des Sanitäts-Comitees in Riga 1866. - Riga, 1867. - S. 22; 36.

7. Schrenck $B$. Beiträge zur Statistik der Stadt Riga und ihrer Verwaltung. - Riga, 1909. - I Band. -214 S.

8. Статистический сборник Рижского городского управления. - Рига, 1909. - Ч. I. - C. $55-56 ; 215 ; 172$.

9. Васильев К.Г., Канеп В.В. Развитие медицинского дела в Прибалтийском крае в ХІХ веке. - Рига, 1965. - С. 61-62; 71-73; 91-92; 103.

\section{Establishment of the Riga Municipal Sanitary Committee and its Activities in the $19^{\text {th }}$ Century (Summary)}

By Valda Pundure

The article reviews the establishment of a permanent Sanitary Committee in Riga in 1867 and its activities throughout the $19^{\text {th }}$ century. A short characterisation of the social economic conditions in the city of Riga during the $19^{\text {th }}$ century is presented. The most widespread infectious diseases and epidemics are mentioned, which caused to improve the sanitary hygienic conditions in Riga. The article points out that the initiators of the creation of a Sanitary committee were 16 Riga municipal doctors; the tasks of the committee were confirmed by a special instruction and the Sanitary committee had only consultative functions. The article reviews the various aspects of the activities of the Sanitary committee (from 1879 - the Sanitary commission) and the ever increasing scope of activities of the Sanitary committee up to the end of the $19^{\text {th }}$ century.

\section{Valda Pundure}

Paula Stradiña Medicīnas vēstures muzejs

Antonijas iela 1, Rīga LV-1360, Latvija

E-mail: museum2@apollo.lv 